\title{
SALINE WATER AND NITROGEN FERTILIZATION ON LEAF COMPOSITION AND YIELD OF CORN ${ }^{1}$
}

\author{
GEOCLEBER GOMES DE SOUSA ${ }^{2}$, HENDERSON CASTELO SOUSA ${ }^{3 *}$, MAX FERREIRA DOS SANTOS ${ }^{4}$, CARLA $^{2}$ \\ INGRYD NOJOSA LESSA ${ }^{3}$, SILAS PRIMOLA GOMES ${ }^{2}$
}

\begin{abstract}
Absence of drainage associated with high evapotranspiration and irregular precipitations contributes to the accumulation of salts in the soil, reducing nutrient absorption and yield. Nutritional management is important for the crop to express its maximum production potential, and nitrogen is the macronutrient most required by the corn crop. The objective of this study was to evaluate yield and leaf contents in corn under different nitrogen fertilization recommendations and salt stress. The experiment was conducted from June to September 2019, at the University of International Integration of Afro-Brazilian Lusophony in Redenção-CE, Brazil. The experimental design used was completely randomized, in a $2 \times 3$ factorial arrangement, with 6 replicates, with two levels of electrical conductivity $\left(0.3 \mathrm{dS} \mathrm{m}^{-1}\right.$ and $\left.3.0 \mathrm{dS} \mathrm{m}{ }^{-1}\right)$ and three nitrogen fertilization recommendations (0,50 and 100\% of the recommendation). The variables analyzed were unhusked ear weight, husked ear weight, yield and leaf contents of $\mathrm{N}, \mathrm{P}, \mathrm{K}, \mathrm{Ca}, \mathrm{Mg}$ and $\mathrm{Na}$. Irrigation with saline water $\left(3.0 \mathrm{dS} \mathrm{m}^{-1}\right)$ reduces the unhusked ear weight, husked ear weight and yield. Nitrogen fertilization recommendations of $50 \%$ and $100 \%$ promoted higher values of unhusked ear weight, husked ear weight and leaf $\mathrm{N}$ contents, but reduced leaf $\mathrm{P}$ contents. The $50 \%$ and $100 \%$ recommendations promote higher yield values for the two levels of electrical conductivity studied $\left(0.3\right.$ and $\left.3.0 \mathrm{dS} \mathrm{m}^{-1}\right)$. The $50 \%$ and $100 \%$ recommendations associated with saline water irrigation increased the leaf contents of $\mathrm{K}, \mathrm{Na}, \mathrm{Mg}$ and $\mathrm{Ca}$.
\end{abstract}

Keywords: Zea mays L. Salinity. Leaf contents.

\section{ÁGUA SALINA E ADUBAÇÃo NITROGENADA NA COMPOSIÇÃo FOLIAR E PRODUTIVIDADE DO MILHO}

RESUMO - A ausência de drenagem associada a elevada evapotranspiração e precipitações irregulares contribuem para o acúmulo de sais no solo reduzindo a absorção de nutrientes e a produtividade. O manejo nutricional é importante para que a cultura expresse seu máximo potencial produtivo, sendo o nitrogênio o macronutriente mais requerido pela cultura do milho. Objetivou-se avaliar a produtividade e os teores foliares na cultura do milho sob diferentes recomendações de adubação nitrogenada e estresse salino. O experimento foi conduzido no período de junho a setembro de 2019, na Universidade da Integração Internacional da Lusofonia Afro-Brasileira em Redenção-CE. O delineamento experimental utilizado foi inteiramente casualizado, em arranjo fatorial $2 \times 3$, com 6 repetições, sendo dois níveis de condutividade elétrica $\left(0,3 \mathrm{dS} \mathrm{m}^{-1}\right.$ e $\left.3,0 \mathrm{dS} \mathrm{m} \mathrm{m}^{-1}\right)$, com três recomendações de adubação nitrogenada (0, 50 e 100\% da recomendação). As variáveis analisadas foram massa da espiga com e sem palha, produtividade e os teores foliares de $\mathrm{N}, \mathrm{P}, \mathrm{K}, \mathrm{Ca}, \mathrm{Mg}$ e $\mathrm{Na}$. A irrigação com água salina, diminui a massa da espiga com e sem palha e a produtividade. As recomendações $50 \%$ e $100 \%$ de adubação nitrogenada proporcionaram maiores valores de massa da espiga com e sem palha e os teores foliares de $\mathrm{N}$, porém diminuíram os de $\mathrm{P}$. As recomendações de $50 \%$ e $100 \%$ proporcionam maiores valores de produtividade nas duas águas estudadas $\left(0,3\right.$ e $\left.3,0 \mathrm{dS} \mathrm{m} \mathrm{m}^{-1}\right)$. As recomendações $50 \%$ e $100 \%$ associadas a irrigação com água salina aumentaram os teores foliares de $\mathrm{K}, \mathrm{Na}, \mathrm{Mg}$ e $\mathrm{Ca}$.

Palavras-chave: Zea mays L. Salinidade. Teores foliares.

\footnotetext{
${ }^{*}$ Corresponding author

${ }^{1}$ Received for publication in 09/23/2020; accepted in 08/24/2021.

${ }^{2}$ Rural Development Institute, Universidade da Integração Internacional da Lusofonia Afro-Brasileira, Redenção, CE, Brazil; sousagg@unilab.edu.br - ORCID: 0000-0002-1466-6458, silas.primola@unilab.edu.br - ORCID: 0000-0002-0577-1563.

${ }^{3}$ Department of Agricultural Engineering, Universidade Federal do Ceará, Fortaleza, CE, Brazil; castelohenderson@gmail.com - ORCID: 0000-0001-6588-6832, ingryd.nojosal@gmail.com - ORCID: 0000-0002-7793-9150.

${ }^{4}$ Departament of Soil Sciences, Universidade Federal do Ceará, Fortaleza, CE, Brazil; maxsantosferreira@gmail.com - ORCID: 0000-0002 $-6597-8865$.
} 


\section{INTRODUCTION}

Irrigation is a practice that can guarantee agricultural production in arid and semi-arid regions of northeastern Brazil. However, the absence of drainage associated with high evapotranspiration and irregular precipitation contributes to the accumulation of salts in the soil, reducing the availability of water to plants, absorption of nutrients and yield (COSTA; MEDEIROS, 2017; COSTA et al., 2018; RODRIGUES et al., 2020).

Corn (Zea mays L.) is one of the most produced crops in the world, standing out as an important source of food and income for many producers in the semi-arid region. It is one of the main cereals produced in Brazil, being used in human and animal diets, cultivated in 17,309.1 thousand ha, and reaching an average yield of 5,605 $\mathrm{kg} \mathrm{ha}{ }^{-1}$. However, many farmers still perform inadequate management for the crop, mainly related to fertilization (DANTAS JUNIOR et al., 2016; CONAB, 2019).

Nutritional management is important for the corn crop to express its maximum production potential (ZUCARELI et al., 2019). However, in saline environments the ionic interactions that affect the availability, absorption and transport of nutrients are even more complex, mainly due to differences in concentration and ionic composition (higher accumulation of $\mathrm{Na}^{+}$and $\mathrm{Cl}^{-}$), resulting in lower absorption and concentrations of $\mathrm{N}, \mathrm{P}, \mathrm{K}, \mathrm{Ca}$ and $\mathrm{Mg}$ (SOUSA et al., 2010; IBRAHIM et al., 2018).

Among the primary macronutrients, nitrogen (N) is the one most required by corn crop, directly participating in its growth and development. However, when the crop is cultivated in a saline environment under insufficient quantities, there is a reduction in the absorption and translocation of this mineral element, which causes lower growth, low photosynthetic rates, low chlorophyll content and reduced yield (PRADO, 2008; COSTA et al., 2018).

Thus, adequate nitrogen fertilization has been the object of study under conditions of salt stress as an alternative to mitigate these effects, due to its contribution in osmotic adjustment and protection of cellular functions and structures (SOUSA et al., 2021). Ibrahim et al. (2018) observed reductions in the deleterious effects of salinity on production after nitrogen application.

In view of this context, the objective was to evaluate yield and leaf contents in corn crop under different recommendations of nitrogen fertilization and salt stress.

\section{MATERIAL AND METHODS}

The experiment was conducted in full sun at the Auroras Seedling Production Unit (Unidade de Produção de Mudas Auroras - UPMA), belonging to the University of International Integration of AfroBrazilian Lusophony (Universidade da Integração Internacional da Lusofonia Afro-Brasileira UNILAB), in the municipality of Redenção-CE, Brazil, from June to September 2019. The climate of the region is Aw, that is, tropical climate with dry season in winter and average temperatures of the hottest month above $38{ }^{\circ} \mathrm{C}$ and the coldest month below $20^{\circ} \mathrm{C}$ (KÖPPEN, 1923).

The experimental design was completely randomized (CRD), in a $2 \times 3$ factorial arrangement, with 6 replicates, corresponding to two levels of electrical conductivity of irrigation water - ECw: (public-supply water of $0.3 \mathrm{dS} \mathrm{m}^{-1}$ and saline solution of $3.0 \mathrm{dS} \mathrm{m} \mathrm{m}^{-1}$ ) and with three nitrogen recommendations $(0,50$ and $100 \%)$.

The recommendation of nitrogen fertilization was based on Queiroz et al. (2011), using urea $(45 \% \mathrm{~N})$, corresponding to $160 \mathrm{~kg} \mathrm{ha}^{-1}$ of $\mathrm{N}(100 \%)$, split and applied at 19, 26, 33, 40, 47 and 54 days after sowing (DAS).

Sowing was performed in flexible plastic pots with a volumetric capacity of 25 liters (L), by placing five seeds per pot. The corn (Zea mays L.) seeds used in the experiment correspond to the hybrid AG 1051. At 12 DAS, thinning was performed, leaving only one plant per pot.

The substrate used in each pot was composed of arisco (light-textured sandy material normally used in civil construction in Northeastern Brazil), sand and manure in the proportion of $3: 1: 1$, respectively, whose chemical analysis according to the methodology of Teixeira et al. (2017), is presented in Table 1.

Table 1. Chemical characteristics of the substrate used.

\begin{tabular}{|c|c|c|c|c|c|c|c|c|c|}
\hline $\mathrm{OM}$ & $\mathrm{N}$ & $\mathrm{P}$ & $\mathrm{Mg}$ & $\mathrm{K}$ & $\mathrm{Ca}$ & $\mathrm{Na}$ & \multirow{2}{*}{$\begin{array}{c}\mathrm{pH} \\
\mathrm{H}_{2} \mathrm{O}\end{array}$} & \multirow{2}{*}{$\operatorname{ESP}(\%)$} & \multirow{2}{*}{$\begin{array}{l}\text { ECse } \\
\mathrm{dS} \mathrm{m}{ }^{-1}\end{array}$} \\
\hline$-----\frac{9}{9}$ & ------ & $\mathrm{mg} \mathrm{kg}^{-1}$ & \multicolumn{4}{|c|}{ 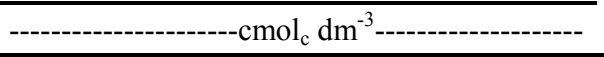 } & & & \\
\hline 4.34 & 0.26 & 65 & 1.2 & 0.65 & 1.2 & 0.33 & 6.2 & 7 & 1.19 \\
\hline
\end{tabular}

$\mathrm{OM}=$ organic matter; $\mathrm{ECse}=$ electrical conductivity of soil saturation extract; $\mathrm{ESP}=$ exchangeable sodium percentage.

The treatments with saline water started at 10 DAS and the applications of the recommended nitrogen doses started at 15 DAS, after the establishment of the crop. 
The irrigation water was prepared by dissolving soluble salts $\left(\mathrm{NaCl}, \mathrm{CaCl}_{2} \cdot 2 \mathrm{H}_{2} \mathrm{O}\right.$ and $\mathrm{MgCl}_{2} \cdot 6 \mathrm{H}_{2} \mathrm{O}$ ), in the equivalent ratio of $7: 2: 1$ of $\mathrm{Na}$, $\mathrm{Ca}$ and $\mathrm{Mg}$, following the relationship between $\mathrm{ECW}$ and their concentration (mmolc $\left.\mathrm{L}^{-1}=\mathrm{EC} \times 10\right)$, according to the methodology contained in Rhoades, Kandiah and Mashali (2000). Irrigation was manually applied daily and calculated according to the drainage lysimeter principle (BERNARDO et al., 2019), keeping the soil at field capacity.

At 90 DAS, harvest was performed and the material collected in full sun began to be dried; subsequently, the evaluations of unhusked ear weight and husked ear weight were performed using an analytical balance and the yield was expressed in $\mathrm{g} \operatorname{pot}^{-1}$.

To evaluate leaf contents, the plant material was crushed in a Wiley-type mill for determining the macronutrients. $\mathrm{N}$ was determined by the wet digestion procedure, followed by steam distillation and titration to quantify $\mathrm{NH}_{4}$ by the semi-micro Kjeldahl method (MIYAZAWA et al., 2009).

The others $(\mathrm{P}, \mathrm{K}, \mathrm{Mg}$ and $\mathrm{Ca})$, along with sodium $(\mathrm{Na})$, were determined by dry digestion in muffle furnace using a $1 \% \mathrm{HNO}_{3}$ solution as extractant. A 500-mg sample of plant tissue was incinerated in electric muffle furnace at a temperature between 500 and $550{ }^{\circ} \mathrm{C}$. The resulting ash was dissolved in nitric acid solution.

The resulting extract was used to determine $\mathrm{P}$, $\mathrm{K}, \mathrm{Mg}, \mathrm{Ca}$ and $\mathrm{Na}$. $\mathrm{K}$ and $\mathrm{Na}$ readings were taken by flame photometry, $\mathrm{P}$ readings by spectrophotometry with molybdenum blue and $\mathrm{Mg}$ and $\mathrm{Ca}$ readings by atomic absorption spectrophotometry (SILVA, 2009).

After collection, the data were subjected to analysis of variance (ANOVA) and Tukey test at $1 \%$ $(* *)$ and $5 \%(*)$ probability levels, using the computer program ASSISTAT 7.7, Beta (SILVA; AZEVEDO, 2016).

\section{RESULTS AND DISCUSSION}

According to the analysis of variance (Table 2), there were individual effects of salinity and recommendations on $\mathrm{N}$ and $\mathrm{P}$. On the other hand, $\mathrm{K}$, $\mathrm{Mg}, \mathrm{Ca}$ and $\mathrm{Na}$ were significantly influenced $(\mathrm{p}<$ 0.01 or $p<0.05$ ) by the interaction between the factors.

Table 2. Summary of the analysis of variance for leaf contents of nitrogen $(\mathrm{N})$, phosphorus $(\mathrm{P})$, potassium $(\mathrm{K})$, magnesium $(\mathrm{Mg})$, calcium $(\mathrm{Ca})$ and sodium $(\mathrm{Na})$ in corn plants under different recommendations of nitrogen fertilization and salt stress.

\begin{tabular}{cccccccc}
\hline \multirow{2}{*}{ SV } & DF & \multicolumn{7}{c}{ Mean Squares } \\
\cline { 3 - 7 } & & $\mathrm{N}$ & $\mathrm{P}$ & $\mathrm{K}$ & $\mathrm{Mg}$ & $\mathrm{Ca}$ & $\mathrm{Na}$ \\
\hline Salinity (S) & 1 & $155.58^{* *}$ & $239.18^{* *}$ & $13616.46^{*}$ & $19.25^{* *}$ & $2835.47^{* *}$ & $197.69^{* *}$ \\
Recommendation (R) & 2 & $423.45^{* *}$ & $715.08^{* *}$ & $23326.00^{* *}$ & $6.44^{*}$ & $2418.88^{* *}$ & $8503.47^{* *}$ \\
S x R & 2 & $13.95^{\text {ns }}$ & $13.20^{\text {ns }}$ & $22076.48^{* *}$ & $9.77^{*}$ & $727.04^{*}$ & $6758.94^{* *}$ \\
Treatments & 5 & $206.08^{* *}$ & $339.15^{* *}$ & $20884.28^{* *}$ & $10.34^{* *}$ & $1825.46^{* *}$ & $10057.91^{* *}$ \\
Residual & 30 & 4.24 & 16.93 & 2349.07 & 1.54 & 119.48 & 203.63 \\
CV (\%) & - & 9.84 & 13.20 & 11.03 & 18.52 & 37.79 & 19.22 \\
\hline
\end{tabular}

SV: Source of variation; DF: Degrees of freedom; CV (\%): Coefficient of variation *, $* *$ and ${ }^{\text {ns }}=$ Significant at $5 \%, 1 \%$ and not significant, respectively.

The leaf contents of $\mathrm{N}$ were negatively affected by the increase in water electrical conductivity, and such increase led to a value of $18.01 \mathrm{~g} \mathrm{~kg}^{-1}$ with a reduction of $5.88 \mathrm{~g} \mathrm{~kg}^{-1}$ compared to the control treatment (Figure 1A).

The reduction of $\mathrm{N}$ in leaf tissues with increasing electrical conductivity of the water is associated with the accumulation of $\mathrm{NaCl}$, leading to chlorosis in older leaves, and the progression of stress can result in their loss (LIMA et al., 2015; PRADO, 2008). Similar results were found by Costa et al. (2018), who obtained reductions of leaf $\mathrm{N}$ with increasing salinity of irrigation water in corn crop.

Regarding the recommendations, nitrogen contents increased by $9.34 \mathrm{~g} \mathrm{~kg}^{-1}$ and $16.76 \mathrm{~g} \mathrm{~kg}^{-1}$ under the recommendations of $50 \%$ and $100 \%$, respectively (Figure 1B).

It must be emphasized that $\mathrm{N}$ is the nutrient most required by the crop, which accumulates a large part of the nutrient in its shoots, besides having an efficient utilization of 50 to $60 \%$ of the total applied as fertilizer, and urea provides high concentration of nitrogen (QUEIROZ et al., 2011). Increase of nitrogen in leaf tissue was also observed by Valderrama et al. (2014) in corn crop under nitrogen fertilization.

The increase in the electrical conductivity of the water reduced the $\mathrm{P}$ contents in the leaves, and the irrigated treatment with water of $3.0 \mathrm{dS} \mathrm{m} \mathrm{m}^{-1}$ obtained $27.52 \mathrm{mg} \mathrm{kg}^{-1}$ and the control $\left(0.3 \mathrm{dS} \mathrm{m}^{-1}\right)$ obtained $34.81 \mathrm{mg} \mathrm{kg}^{-1}$ (Figure 2A). 

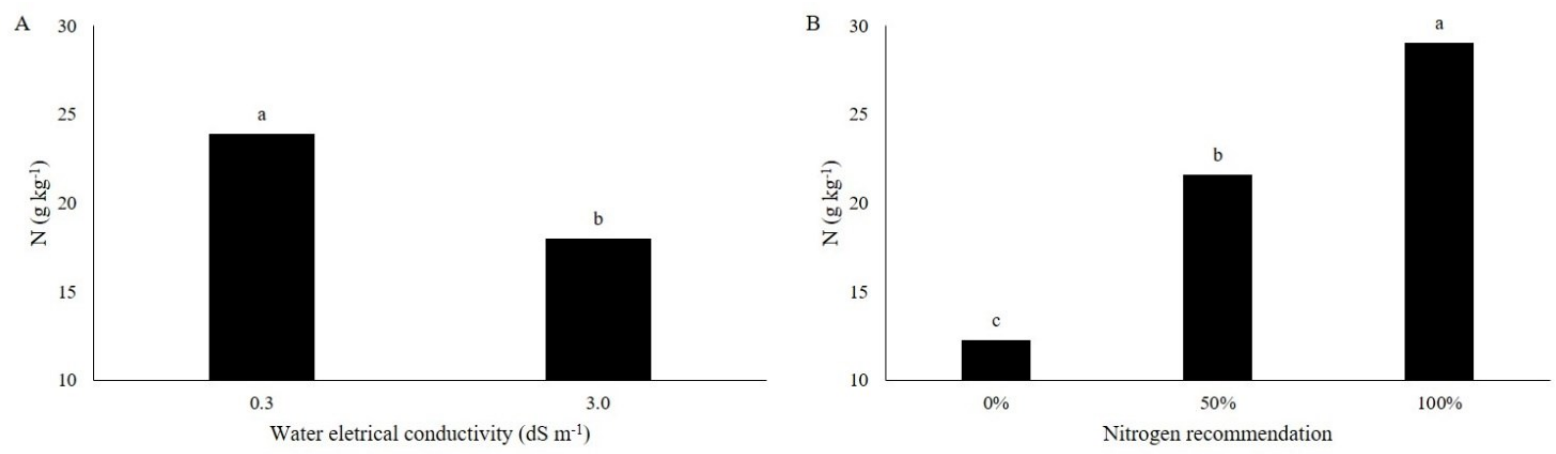

Figure 1. Leaf contents of $\mathrm{N}$ in corn plants as a function of different electrical conductivities of water (A) and nitrogen recommendations (B). Columns followed by the same lowercase letters do not differ significantly from each other by Tukey test $(\mathrm{P} \leq 0.05)$.
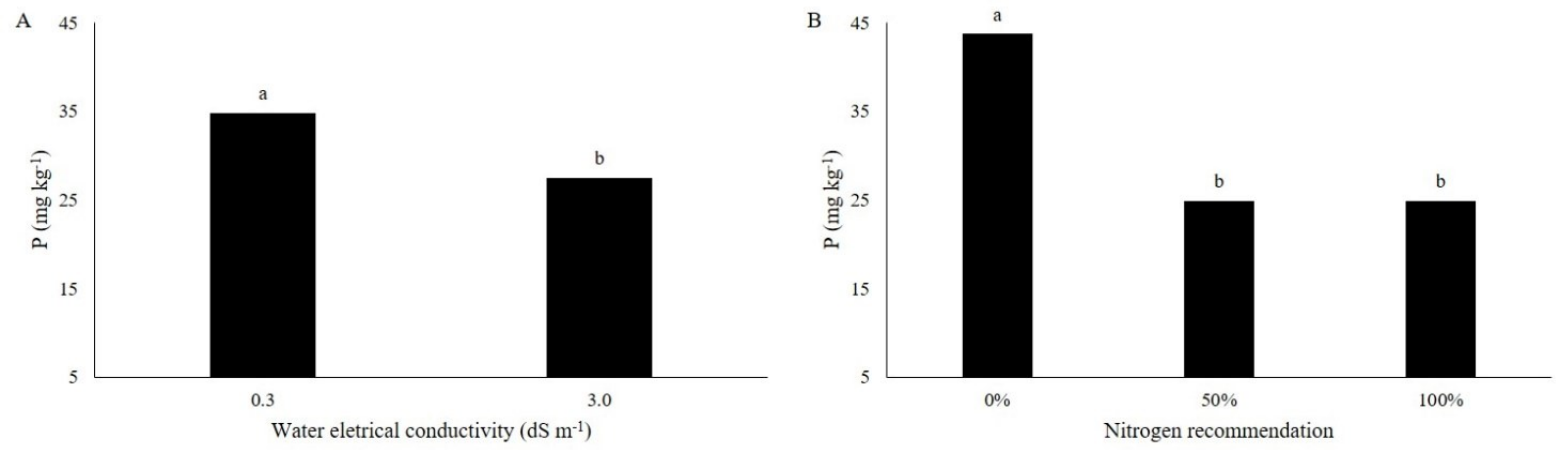

Figure 2. Leaf contents of $P$ in corn plants as a function of different electrical conductivities of water (A) and nitrogen recommendations (B). Columns followed by the same lowercase letters do not differ significantly from each other by Tukey test $(\mathrm{P} \leq 0.05)$.

Phosphorus is affected by salinity due to the effects of ionic force, which cause the decrease of phosphate activity in the soil solution and the reduction of its solubility (SOUSA et al., 2010). Costa et al. (2018) obtained similar results, with reductions in $\mathrm{P}$ content in corn crop as water salinity increased.

According to Figure 2B, the control recommendation $(0 \%)$ promoted the highest $P$ content in the leaves, $43.77 \mathrm{mg} \mathrm{kg}^{-1}$. The decrease in $P$ values with the increase of nitrogen recommendations can be explained by the fact that the increase in fertilization promotes a greater leaf development and emergence of new organs (PRADO, 2008), compared to the control treatment, thus leading to a lower concentration of the nutrient in some parts of the plant, known as dilution effect (GOBBO-NETO; LOPES, 2007).

Phosphorus is one of the most important nutrients for the formation of corn grains (COSTA et al., 2018), in addition to stimulating growth and being an enzymatic constituent (PRADO, 2008). A similar trend was observed by Santos et al. (2015), who verified a reduction of $\mathrm{P}$ with the application of nitrogen in sorghum plants.

Figure $3 \mathrm{~A}$ shows that the leaf content of potassium was statistically higher than those of the others only when the crop was irrigated with water of $3.0 \mathrm{dS} \mathrm{m} \mathrm{m}^{-1}$ associated with a recommendation of $50 \%$ (597.96 mg kg-1). This result reveals that plants irrigated with low-salinity water compartmentalized $\mathrm{K}$ among their tissues more than plants irrigated with high-salinity water, that is, the presence of nitrogen may have caused reduction in the translocation of $\mathrm{NaCl}$ to the shoots, forcing a form of adaptation of the plant to salt stress, thus promoting higher values of $\mathrm{K}$ in the leaves (FEIJÃO et al., 2011).

Increase in the leaf content of $\mathrm{K}$ after nitrogen fertilization has also been verified by Santos et al. (2015) and Lima et al. (2015) in sorghum and castor bean crops, respectively.

The sodium content present in the leaves (Figure 3B) was statistically higher under highsalinity water for all recommendations. The observed increase shows that there were no mechanisms of exclusion of toxic ions $\left(\mathrm{Na}^{+}\right)$, after leaf absorption, possibly associated with the acclimatization, where the plants adjusted their morphophysiological processes to withstand salt stress (LIMA et al., 2015; TAIZ et al., 2017).

Similar results were found by Lima et al. (2015) in castor bean and Feijão et al. (2011) in Sudan sorghum plants when they recorded an increase in the leaf content of $\mathrm{Na}$ after irrigation with saline water and application of $\mathrm{N}$ doses. 

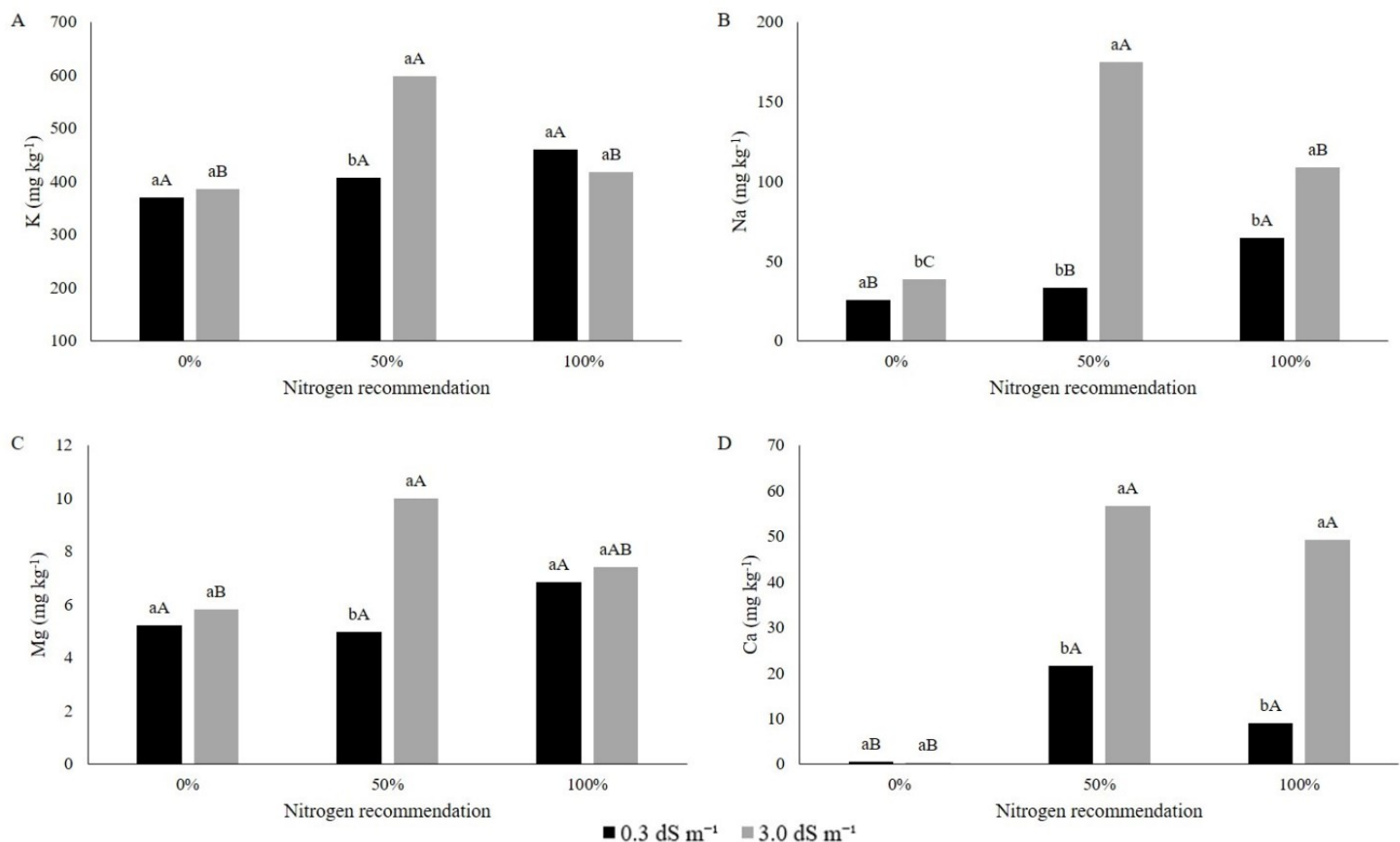

Figure 3. Leaf contents of $\mathrm{K}(\mathrm{A}), \mathrm{Na}(\mathrm{B}), \mathrm{Mg}(\mathrm{C})$ and $\mathrm{Ca}(\mathrm{D})$ in corn plants as a function of different nitrogen recommendations and electrical conductivities of water. Columns followed by the same lowercase letters at the same nitrogen recommendation level - or uppercase letters at the same salinity level, do not differ significantly from each other by Tukey test $(\mathrm{P} \leq 0.05)$.

The leaf contents of magnesium (Figure 3C) followed the same trend as those of $\mathrm{K}$ (Figure $3 \mathrm{~A}$ ), that is, the recommendation of $50 \%$ with highsalinity water was statistically better. This increase in $\mathrm{Mg}$ content under salt stress may be related to the presence of $\mathrm{MgCl}$ in irrigation water or the adaptation in accumulating $\mathrm{Mg}$ in a saline environment, as it is the second nutrient most extracted by corn plants irrigated with salinity of up to $3.6 \mathrm{dS} \mathrm{m}^{-1}$ (SOUSA et al., 2010). It is worth pointing out that magnesium is the central element of chlorophyll, being essential for chloroplasts, which are organelles that contain the thylakoids, favoring photosynthesis (TAIZ et al., 2017).

Similar results were obtained by Costa et al. (2018), who observed an increase of $\mathrm{Mg}$ in leaves of corn irrigated with saline water. Increase in the leaf content of $\mathrm{Mg}$ was also observed by Dantas Neto et al. (2013), in the guava crop fertigated with nitrogen.

The contents presented in Figure 3D show that high-salinity water increased them by 56.66 and $49.24 \mathrm{mg} \mathrm{kg}^{-1}$ under the recommendations $50 \%$ and $100 \%$, respectively, not differing statistically from each other, but being superior to the recommendation of $0 \%$.

The increase in the leaf contents of $\mathrm{Ca}$ with saline water irrigation may be related to the mixture of salts used in the study (sodium, calcium and magnesium) or to the mechanism used by plants to tolerate the large amount of toxic ions such as sodium (Na) in corn plants (SOUSA et al., 2010; TAIZ et al., 2017).

Calcium constitutes the cell wall, participates in its elongation and division, and can enhance the number and mass of ears (JAVORSKI et al., 2015). A similar trend was observed by Costa et al. (2018), who recorded an increase in $\mathrm{Ca}$ contents in corn leaves, at the highest salinity levels. Sousa et al. (2012) found a linear increase in the leaf contents of calcium with the increase in the electrical conductivity of irrigation water in the jatropha crop.

According to Table 3, the variables unhusked ear weight and husked ear weight were influenced individually by the factors salinity and nitrogen recommendation. Yield was influenced $(\mathrm{p}<0.01$ or $p<0.05)$ by the interaction between the two factors.

According to Figure 4 (A and $\mathrm{B}$ ), the treatments that received water with lower electrical conductivity had statistically higher values (58.26 and 43.69, respectively).

Salt stress induced by irrigation can lead to progressive disorders such as osmotic, nutritional and toxicity stresses, affecting physiological and morphological processes consequently affecting yield components (LACERDA et al., 2011). Rodrigues et al. (2020) obtained similar results with reductions in unhusked and husked ear weights due to increased salinity of irrigation water. 
Table 3. Summary of the analysis of variance for unhusked ear weight (UEW), husked ear weight (HEW) and yield (Y) of corn plants under different recommendations of nitrogen fertilization and salt stress.

\begin{tabular}{ccccc}
\hline SV & DF & \multicolumn{3}{c}{ Mean Squares } \\
\cline { 3 - 5 } & & UEW & HEW & Y \\
\hline Salinity (S) & 1 & $3858.92^{* *}$ & $2252.13^{* *}$ & $192409.27^{* *}$ \\
Recommendation (R) & 2 & $7472.24^{* *}$ & $5437.54^{* *}$ & $149136.34^{* *}$ \\
S x R & 2 & $684.98^{\text {ns }}$ & $258.57^{\text {ns }}$ & $3770.84^{* *}$ \\
Treatments & 5 & $4034.87^{* *}$ & $2728.87^{* *}$ & $113217.13^{* *}$ \\
Residual & 30 & 209.08 & 172.68 & 1444.82 \\
CV (\%) & - & 30.18 & 36.72 & 21.46 \\
\hline
\end{tabular}

SV: Source of variation; DF: Degrees of freedom; CV (\%): Coefficient of variation *, ${ }^{* *}$ and ${ }^{\mathrm{ns}}=$ Significant at $5 \%, 1 \%$ and non-significant, respectively.
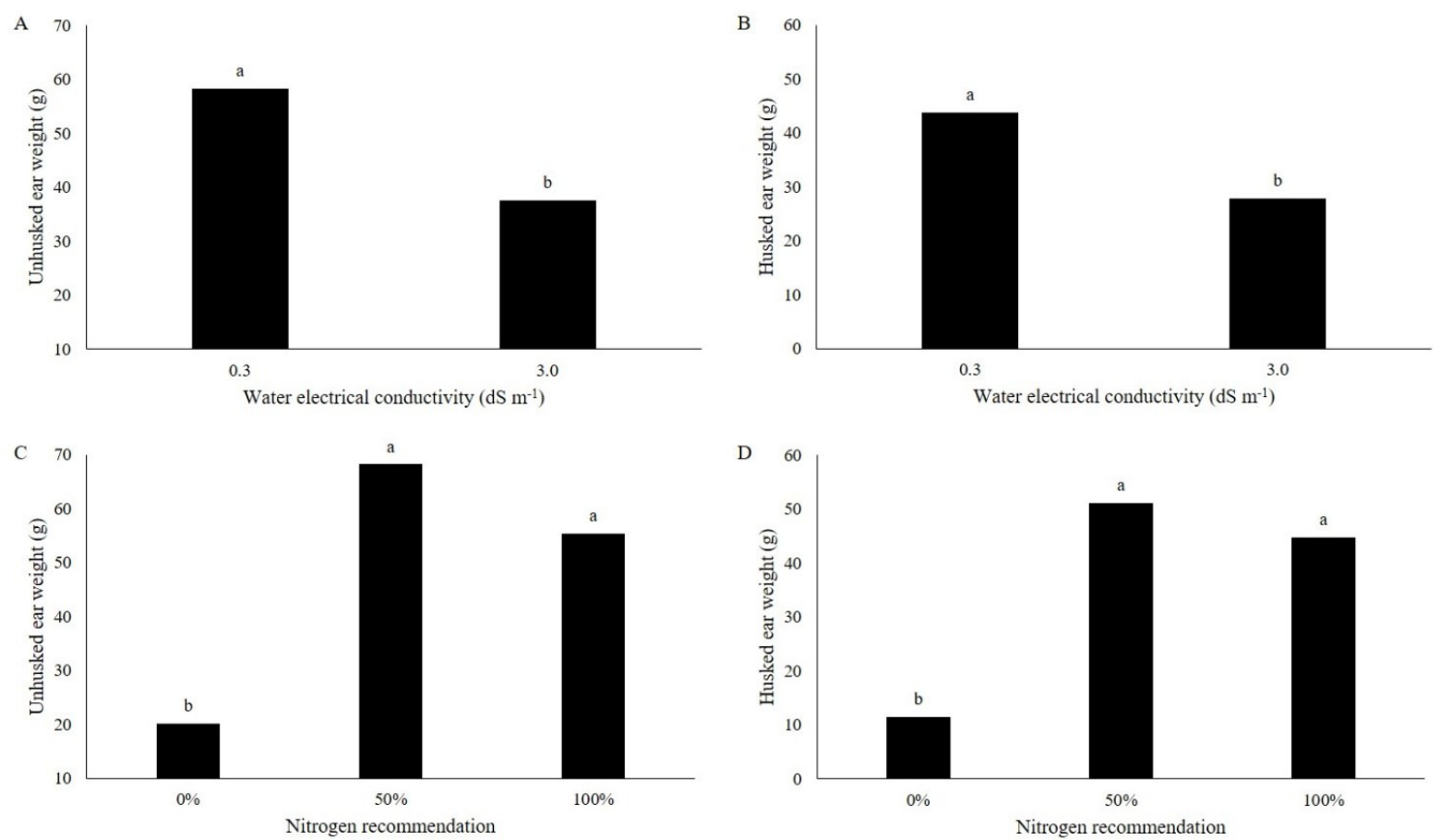

Figure 4. Unhusked ear weight (A-C) and husked ear weight (B-D) of corn plants as a function of different nitrogen recommendations and electrical conductivities of water. Columns followed by the same lowercase letters do not differ significantly from each other by Tukey test $(\mathrm{P} \leq 0.05)$.

For the nitrogen recommendation factor (Figures 4C; D), the treatments with $50 \%$ and $100 \%$ were statistically superior, differing from the control treatment $(0 \%)$. This effect in the present study corroborates the information of Carmo et al. (2012), who stated that the availability of $\mathrm{N}$ increases the potential of corn plants to produce a higher number of grains per ear.

Similar results were found by Carmo et al. (2012), who observed higher values of unhusked and husked ear weights with increasing dose of nitrogen fertilization using urea.

For yield (Figure 5), low-salinity water associated with all recommendations was statistically superior to high-salinity water $(0 \%=71.14 ; 50 \%=$ 393.55 and $\left.100 \%=286.08 \mathrm{~g} \mathrm{pot}^{-1}\right)$, but at this conductivity level $\left(3.0 \mathrm{dS} \mathrm{m}^{-1}\right)$ the recommendations 50 and $100 \%$ promoted higher yield (129.62 and $152.07 \mathrm{~g} \mathrm{pot}^{-1}$, respectively), compared to treatment without fertilization, indicating that $\mathrm{N}$ application can relieve the stresses imposed by the saline condition of the water (IBRAHIM et al., 2018).

Increase in corn crop yield was also reported by Valderrama et al. (2014), who obtained higher values of 100 grain weight, number of grains per ear and linear increase in yield with the increase of $\mathrm{N}$ doses applied. 


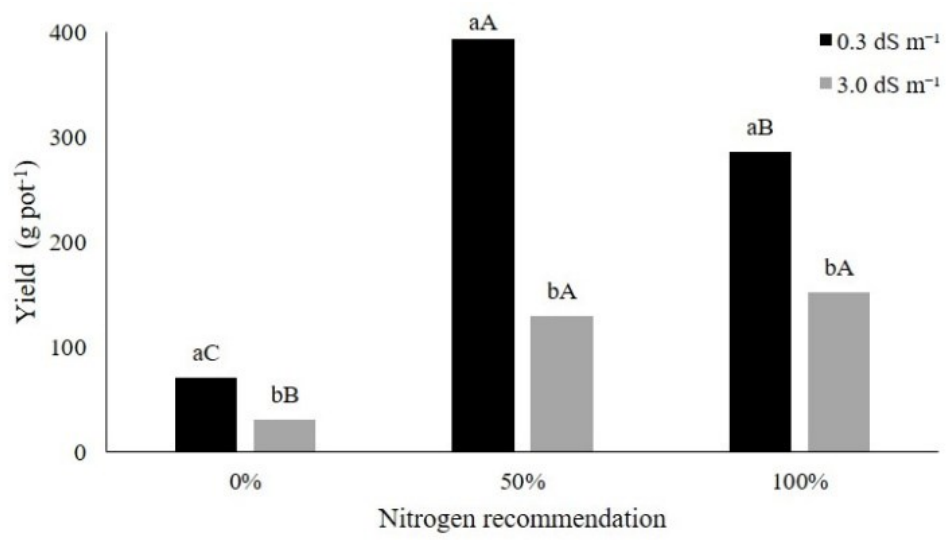

Figure 5. Yield of corn crop as a function of different nitrogen recommendations and electrical conductivities of water. Columns followed by the same lowercase letters at the same nitrogen recommendation level - or uppercase letters at the same salinity level, do not differ significantly from each other by Tukey test $(\mathrm{P} \leq 0.05)$.

When high-salinity water was used, there was a reduction, effectively showing the negative effects caused by the salts, such as lower water and nutrient uptake, directly affecting yield (TAIZ et al., 2017; RODRIGUES et al., 2020).

Similar results were reported by Ibrahim et al. (2018), who found that $\mathrm{N}$ reduced some deleterious effects of salts on the wheat crop, promoting higher values in the variables number and weight of grains per ear, thousand-grain weight and yield.

Rodrigues et al. (2020), working under field conditions, found that the increase in salt concentration in irrigation water caused reductions in unhusked and husked ear weights, thousand-grain weight and yield of corn.

\section{CONCLUSIONS}

Leaf contents of $\mathrm{N}$ and $\mathrm{P}$ were reduced with salt stress, whereas from the fertilization recommendations $(50 \%$ and $100 \%)$ the $\mathrm{N}$ values increased progressively and $\mathrm{P}$ values decreased.

Association of saline water irrigation with the nitrogen recommendations of $50 \%$ and $100 \%$ increased leaf contents in the following order: $\mathrm{K}>$ $\mathrm{Na}>\mathrm{Ca}>\mathrm{Mg}$.

Nitrogen fertilization corresponding to $50 \%$ and $100 \%$ promoted higher unhusked and husked ear weights, but these variables are reduced under salt stress.

The yield of the hybrid corn AG 1051 was higher from nitrogen recommendations $(50 \%$ and $100 \%$ ), regardless of the electrical conductivity of the water $\left(0.3\right.$ and $\left.3.0 \mathrm{dS} \mathrm{m}^{-1}\right)$.

\section{REFERENCES}

BERNARDO, S. et al. Manual de irrigação. 9. ed.
Viçosa, MG: Editora UFV, 2019. 545 p.

CARMO, M. S. et al. Doses e fontes de nitrogênio no desenvolvimento e produtividade da cultura de milho doce (Zea Mays convar. saccharata var. rugosa). Bioscience Journal, 28: 223-231. 2012.

CONAB - Companhia Nacional de Abastecimento. Ministério da Agricultura, Pecuária e Abastecimento Safra Brasileira de Grãos: Boletim de grãos 2019/2020. 2019. Disponível em: <https:// www.conab.gov.br/infoagro/s-afras/graos-/boletimda-safra-de-graos>. Acesso em: 20 Mai. 2020.

COSTA, A. R. F. C.; MEDEIROS, J. F. Água salina como alternativa para irrigação de sorgo para geração de energia no Nordeste brasileiro. Water Resources and Irrigation Management-WRIM, 6: 169-177, 2017.

COSTA. M. E. et al. Massa seca e teores de nutrientes de plantas de milho sob efeito de águas salinas e biochar. Revista Verde de Agroecologia e Desenvolvimento Sustentável, 13: 672-682, 2018.

DANTAS JUNIOR, E. E. et al. Lâminas de irrigação localizada e adubação potássica na produção de milho verde, em condições semiáridas. Revista Espacios, 37: 1-9, 2016.

DANTAS NETO, J. et al. Teores de macronutrientes em folhas de goiabeira fertirrigada com nitrogênio. Revista Brasileira de Engenharia Agrícola e Ambiental, 17: 962-968, 2013.

FEIJÃO, A. R. et al. Efeito da nutrição de nitrato na tolerância de plantas de sorgo sudão à salinidade. Revista Ciência Agronômica, 42: 675-683, 2011.

GOBBO-NETO, L.; LOPES, N. P., Plantas 
medicinais: fatores de influência no conteúdo de metabólitos secundários. Química Nova, 30: 374381, 2007.

IBRAHIM, M. E. H et al. Fertilizante nitrogenado reduz o impacto do cloreto de sódio no rendimento de trigo. Agronomy Journal, 110: 1731-1737, 2018.

JAVORSKI, M. et al. Rendimento de sementes de milho em função da adubação foliar com cálcio e boro no estádio fenológico (V6). Revista Cultivando o Saber, 8: 132-142, 2015.

KÖPPEN, W. P. Die klimate der erde: Grundriss der klimakunde. Berlin: Walter de Gruyter \& So., $1923.369 \mathrm{p}$.

LACERDA, C. F. et al. Salinização do solo e produtividade de milho e feijão caupi em sistema de rotação cultural utilizando águas salinas. Engenharia Agrícola, 31: 663-675, 2011.

LIMA, G. S. et al. Crescimento, teor de sódio, cloro e relação iônica na mamoneira sob estresse salino e adubação nitrogenada. Comunicata Scientiae, 6: 212-223, 2015.

MIYAZAWA, M. et al. Análises químicas de tecido vegetal. In: SILVA, F. C. (Ed.). Manual de análises químicas de solos, plantas e fertilizantes. 2. ed. Brasília, DF: EMBRAPA, 2009. cap. 1, p. 190-223.

PRADO, R. M. Nutrição de plantas. 1. ed., São Paulo, SP: UNESP, 2008. 407 p.

QUEIROZ, A. M. et al. Avaliação de diferentes fontes e doses de nitrogênio na adubação da cultura do milho (Zea Mays L.). Revista Brasileira de Milho e Sorgo, 10: 257-266, 2011.

RHOADES, J. D.; KANDIAH, A.; MASHALI, A. $M$. Uso de águas salinas para produção agrícola. 1. ed. Campo Grande, PB: UFPB, 2000. 117 p. (Estudos FAO. Irrigação e Drenagem, 48).

RODRIGUES, V. S. et al. Produtividade da cultura do milho irrigado com águas salinas. Revista Brasileira de Engenharia Agrícola e Ambiental, 24: 101-105, 2020 .

SANTOS, F. C. et al. Adubação nitrogenada e potássica na nutrição e na extração de macronutrientes pelo sorgo biomassa. Revista Brasileira de Milho e Sorgo, 14: 10-22, 2015.

SILVA, C. S. Manual de análises químicas de solos, plantas e fertilizantes. 2. ed. Brasília, DF: Embrapa Solos, 2009. 627p.
SILVA, F. A. S.; AZEVEDO, C. A. V. The Assistat Software Version 7.7 and its use in the analysis of esperimental data. African Journal of Agricultural Research, 11: 3733-3740, 2016.

SOUSA, A. E. C. et al. Teores de nutrientes foliares e respostas fisiológicas em pinhão manso submetido a estresse salino e adubação fosfatada. Revista Caatinga, 25: 144-152, 2012.

SOUSA, G. G. et al. Nutrição mineral e extração de nutrientes de planta de milho irrigada com água salina. Revista Brasileira de Engenharia Agrícola e Ambiental, 14: 1143-1151, 2010.

SOUSA, H. C. et al. Crescimento e trocas gasosas do milho sob estresse salino e doses de nitrogênio. Revista Brasileira de Engenharia agrícola e Ambiental, 25: 174-181, 2021.

TAIZ, L. et al. Fisiologia e desenvolvimento vegetal. 6. ed. Porto Alegre, RS: Artmed, 2017. 858 p.

TEIXEIRA, P. C. et al. Manual de Métodos de Análise de Solo, 3. ed., Brasília, DF: Embrapa, 2017. $573 \mathrm{p}$

VALDERRAMA, M. et al. Adubação nitrogenada na cultura do milho com ureia revestida por diferentes fontes de polímeros. Semina: Ciências Agrárias, 35: 659-670, 2014.

ZUCARELI, C. et al. Densidade de plantas e adubação nitrogenada em cobertura no desenvolvimento e desempenho produtivo do milho. Revista Brasileira de Milho e Sorgo, 18: 178-191, 2019. 